\title{
LEAD CONTAMINATION IN SOIL OF YOGYAKARTA CITY, INDONESIA
}

\author{
Wawan Budianta* \\ Department of Geological Engineering, Gadjah Mada University, Yogyakarta, Indonesia
}

\begin{abstract}
This paper investigates on $\mathrm{Pb}$ concentrations and mobility in soil of overall Yogyakarta City, Indonesia. The objectives of this study include to investigate $\mathrm{Pb}$ concentrations in the surface soil throughout Yogyakarta and to study their possible sources and potential environmental impacts. The soil samples from 168 locations in Yogyakarta was obtained, representing different land use and traffic conditions. Spatial analysis and sequential extraction analysis were performed. Generally, contour pattern of $\mathrm{Pb}$ value clearly shows that high value is concentrated in the middle and few north part of the study area, confirmed by traffic condition in the study area. In general, the results of sequential extraction analysis shows that $\mathrm{Pb}$ was predominantly associated with exchangeable fraction. The presence of lead in the exchangeable fractions may pose a serious environmental concern since they are highly soluble and potentially bio-available in the soil of study area.
\end{abstract}

Keywords: Soil, lead contamination, GIS, sequential extraction.

\section{Introduction}

Anthropogenic activities in urban areas concentrate potential toxic materials, such as lead $(\mathrm{Pb})$ that may be inadvertently or deliberately released into the environment. Human exposure to these toxins may inevitably result in adverse effects on health that may be either accute or chronic. Thus, it becomes imperative that

*Corresponding author: W. BUDIANTA, Department of Geological Engineering, Faculty of Engineering, Gadjah Mada University, Jl. Grafika 2 Yogyakarta, 55281, Indonesia. E-mail: wbudianta@ugm.ac.id concentrations of $\mathrm{Pb}$ and other hazardous materials in the environment must be adequately examined in order to support a development of regulations and standards to minimize the risks associated with these materials in urban areas. Lead emissions from vehicles are the major source of the contamination, and the nature of the source ensures wide dispersion of the pollutant. Since there is a continuous intercompartmental exchange of $\mathrm{Pb}$ among air, water, and soil, most airborne $\mathrm{Pb}$ is eventually deposited onto some surface, including soil, plants, water bodies, artificial surfaces, and the respiratory tracts of animal and human by dry or wet deposition processes. $\mathrm{Pb}$ is a good indicator of contamination in soil because it appears in gasoline, car components, oil lubricants, industrial and incinerator emissions. $\mathrm{Pb}$ in soil results mainly from dry and wet deposition of atmospheric $\mathrm{Pb}$, particularly close to emission sources, as well as its natural occurence in soil (Alloway, 1990).

Yogyakarta City is located in the central part of Java Island. In the 1930's, Yogyakarta was just a small town in the interior of Java with a population of approximately 60.000 inhabitants (Baiquni, 2004). In the last two decades, urbanization has transformed the structures of Yogyakarta City and it grows beyond its administrative boundary with about one million inhabitants (Subanu, 2004). Urbanization has transformed rural dwellings to become urban settlements and generated an urban agglomeration area. The Yogyakarta urban agglomeration area consists of the Yogyakarta City municipality and two regencies, i.e., Sleman and Bantul. Percentage of urban population in the Yogyakarta 
Province has significantly increased from $22 \%$ in 1980 to $58 \%$ in 2000 . This increase has simultaneously occurred with the growth of the urban area. The population density in the Yogyakarta City municipality area varies between 10,000 to 30,000 person $/ \mathrm{km}^{2}$, while the population density in its agglomeration area ranges between 1,000 to 3,000 person $/ \mathrm{km}^{2}$. Since the 1980s, rapid urbanization has been taking place in the north part with a number of residentials built up in the north and west parts of the traditional agricultural area. The new residentials usually consist of residential and commercial sites. The development of the number of vehicles that create rapid air quality change in the city of Yogyakarta is increased. In addition to cause air pollution, the development of vehicles noise triggers threshold beyond normal level.

$\mathrm{Pb}$ has been added to gasoline since the early 1920s as tetraethyl and tetramethyl lead to make combustion more efficient. However, research shows that the $\mathrm{Pb}$ emitted through the exhaust system had a detrimental effect on the environment with estimates that over $75 \%$ of environmental $\mathrm{Pb}$ was derived from this source. The use of lead-containing fuel has been used in all countries and gasoline with $\mathrm{Pb}$ additives is still used in many developing countries. The data obtained from the Agency of Environmental Protection of Provincial Government of Yogyakarta throughout 2008 shows that nitrogen dioxide concentration $\left(\mathrm{NO}_{2}\right)$ in the air has exceeded the threshold standard of quality. The findings degree of $\mathrm{NO}_{2}$ in the air was 0.0045$0.0018 \mathrm{ppm}$, or exceeding the limit of 0.0129 ppm standard quality. In addition to $\mathrm{NO}_{2}, \mathrm{~Pb}$ concentration in the air has also exceeded standard quality. Currently, the repetitive measurement in the air around 0.3656-75.7 microgram per cubic meter $\left(\mu \mathrm{g} / \mathrm{m}^{3}\right)$, or exceed the maximum threshold in the air of $2.00 \mu \mathrm{g} / \mathrm{m}^{3}$.

There were previous studies on the distribution of heavy metals in soil in Yogyakarta (Wardhana and Muryono, 2000; Budianta, 2009a; Budianta 2009b; Budianta, 2010). However, this study focuses only on limited locations, particularly along major traffic roads and there is no extensive survey on general soil conditions in Yogyakarta. Pb concentrations in the soil of the overall Yogyakarta environment have never been studied systematically, and the extent of soil contamination in the city remains unknown.

The objectives of this study include the investigation of the concentrations of $\mathrm{Pb}$ in the surface soil throughout Yogyakarta and to study their possible sources and potential environmental impact. The data arises from this study may provide the needed information that may serve as a springboard for action by private and government environmental managers in the attempt to minimize environmental health problems.

\section{Material and Methods}

\subsection{The study area, sampling method and analysis}

The study area is focused in Yogyakarta City and its surroundings which consist of commercial and traditional residential areas that are located in the northern part. The soil samples from 168 locations in Yogyakarta was taken to represent the different land use and traffic conditions. The soil samples was obtained by gridding the study area by $0.5 \mathrm{~km} \times 0.5 \mathrm{~km}$ wide and the samples was obtained in every grid. The area in Yogyakarta City may be classified into two different land use areas, namely urban and suburban areas according to its adjacent land use. Each of the soil samples obtained using a stainless steel hand auger to follow the US EPA standard operation procedure (U.S. Environmental Protection Agency, 2007).

Surface soil from a depth at 0 to $5 \mathrm{~cm}$ is sampled from representative areas. Two to three composite samples was collected within each sampling site. The sampling was designed to investigate $\mathrm{Pb}$ concentrations in representative soil, and thus soil very close to site-specific pollution sources, e.g. landfills, waste stations, industrial plants, gasoline stations, etc., will be avoided except for a few urban soil near highways (urban soil are commonly distributed near highways in Yogyakarta). The soil samples collected are stored in plastic bags for subsequent sample preparation and analysis. Soil samples collected were air-dried at room tem- 
perature for seven days, screened through a 2-mm sieve and then $\mathrm{Pb}$ concentrations will be analyzed by a flame absorption spectrophotomer (AAS) (Varian AA-20).

\subsection{Spatial analysis and sequential extrac- tion}

Analysis Spatial analysis using geostatistics based on Geographic Information System (GIS) was performed. The $\mathrm{Pb}$ concentrations are used as the input data for $\mathrm{Pb}$ soil contamination maps to study the distribution of $\mathrm{Pb}$ in urban soil. The software used for mapping and spatial analysis was Arcview. An interpolation method was determined for the interpolation of the geographical data (Webster and Oliver, 2007; Shi et al, 2002)

Sequential extraction analysis was also conducted and used to operationally define heavy metals into different geochemical phases, usually in the order of increasing stability. A fivestep sequential chemical extraction, commonly referred to as Tessier?s method, is probably one of the most widely used sequential chemical extraction methods (Tessier et al, 1979) that defines metals into five fractions with increasing stability through the use of progressively reactive extractants. The extracted metals from these five consecutive steps are operationally defined into five geochemical fractions: (1) readily soluble and exchangeable; (2) carbonate-bound, specifically adsorbed, and weak organic and inorganic complexes; (3) bound to iron and manganese oxides; (4) bound to stable organic and/or sulphide complexes; and (5) residual fractions containing primary and secondary minerals held within their crystal structure.

It is acknowledged that the reactivity and potential bio-availability of heavy metals generally increases with increasing solubility. Thus, the first two forms are usually considered as the two most mobile forms of metals in soil and are potentially bio-available to plants and animals. The last three are relatively immobile and stable, but may sometimes become mobile and bio-available with changes of soil conditions. In each experiment, 10 gram of soil sample was
Table 1: Heavy metals concentration in major rock type.

\begin{tabular}{c|c|c|c}
\hline \multirow{2}{*}{ Element } & \multicolumn{3}{|c}{ Geologic rock type $^{\mathrm{a}}$} \\
\cline { 2 - 4 } & Ultra-mafic & Mafic & Sandstone \\
\hline $\mathrm{Cd}$ & 0.12 & 0.13 & 0.05 \\
\hline $\mathrm{Co}$ & 110 & 35 & 0.3 \\
\hline $\mathrm{Cr}$ & 2980 & 200 & 35 \\
\hline $\mathrm{Cu}$ & 42 & 90 & 30 \\
\hline $\mathrm{Fe}^{\mathrm{b}}$ & 94000 & - & 9800 \\
\hline $\mathrm{Mn}$ & 1040 & 1500 & 460 \\
\hline $\mathrm{Ni}$ & 2000 & 150 & 9 \\
\hline $\mathrm{Pb}$ & 14 & 3 & 10 \\
\hline $\mathrm{V}$ & 40 & 250 & 20 \\
\hline $\mathrm{Zn}$ & 58 & 100 & 30 \\
\hline
\end{tabular}

Source: ${ }^{a}$ Krauskopf (1967) and Rose et al (1979);

${ }^{\mathrm{b} C a n n o n}(1978)$.

used, and the extraction condition for the sequential extraction analysis.

\section{Results and Discussion}

\subsection{Geology of study area}

The rocks underlying the study area fall within Holocene age. Volcanic rocks and their derivatives dominate the area, particularly in the Yogyakarta Basin where extensive deposit of alluvium that is derived from Merapi Volcano ejects lies. According to Sir M. MacDonald and Partner (1984), Old Merapi Volcanics consist of strongly fractured basalt and andesite lavas, with indurated breccias, outcrops around upper cone of Volcano Merapi and are the deposit of Upper Pleistocene Merapi volcanism. The buried extension of these deposits does not extend far from south. In Yogyakarta, a deep borehole has penetrated the soil through the post Pleistocene deposits directly into tertiary strata.

Soil background samples gives a $\mathrm{Pb}$ concentration of $5 \mathrm{mg} / \mathrm{kg}$. Soil $\mathrm{Pb}$ level was also influenced by the composition of parent materials (Table 1). Native concentrations of $\mathrm{Pb}$ are relatively high in ultra-mafic usually lower in sandstone and mafic rock. Lead in soil is largely insoluble, low in mobility, and seldom leached from the profile. 
Table 2: Several properties soil sample.

\begin{tabular}{l|l}
\hline \multicolumn{1}{c|}{ Properties } & \multicolumn{1}{c}{ Sample } \\
\hline Classification & Sandy loam \\
\hline Sand-Gravel (\%) ${ }^{1)}$ & 77.71 \\
\hline Silt-Clay (\%) ${ }^{1)}$ & 22.9 \\
\hline pH & 7.2 \\
\hline Organic content (\%) ${ }^{2)}$ & 2.88 \\
\hline Specific Surface Area $\left(\mathrm{m}^{2}\right)^{3)}$ & 19.5 \\
\hline Specific Gravity & 2.73 \\
\hline & Quartz, \\
Total Mineralogical & Feldspar, \\
Composition ${ }^{4)}$ & Albite, \\
& Kaolinite, \\
& Illite \\
\hline Cation Exchange & 14 \\
Capacity (meq/100 gram) ${ }^{5)}$ & \\
\hline
\end{tabular}

Analyzed by using:

${ }^{1)}$ Sieving and hydrometer test

2) Total Organic Carbon (TOC) Analyzer

${ }^{3)}$ Brunauer, Emmitt and Teller (BET) method

${ }^{4)} \mathrm{X}$-ray Diffraction

${ }^{5)} \mathrm{BaCl}_{2} \cdot 2 \mathrm{H}_{2} \mathrm{O}$ compulsive exchange method

\subsection{Soil properties}

Several properties of soil samples can be seen in Table 2. The result of grain-size distribution was analyzed by standard methods for soil (ASTM). The average of grain-size distribution indicated that the soil samples contained approximately $10-20 \%$ clay-silt size particles and the remaining is sand. The average $\mathrm{pH}$ of the soil suspension with a ratio by weight of $1: 1$ of soil to water was 6.65. Specific surface area was measured using BET method. Determination of the cation exchange capacity (CEC) used $\mathrm{BaCl}_{2} \cdot 2 \mathrm{H}_{2} \mathrm{O}$ compulsive exchange method. XRay diffraction analysis (powder method) revealed that the samples contained kaolinite, illite, chlorite, quartz and feldspar.

\subsection{Distribution patterns of $\mathbf{P b}$}

The $\mathrm{Pb}$ content of 168 samples that were selected in urban and suburban areas varied widely, ranging from 25 to $95.5 \mathrm{mg} / \mathrm{kg}$. The mean value was $64 \mathrm{mg} / \mathrm{kg}$, 15 times the background value. In this case, $\mathrm{Pb}$ was not associated with lithological factor. It is evident that soil in Yogyakarta city was highly enriched in
Table 3: Summarized statistical obtained data.

\begin{tabular}{c|c|c|c|c}
\hline $\mathrm{N}$ & Min & Maks & Mean & Std. Dev \\
\hline 168 & 16 & 95.20 & 65.4 & 10.18 \\
\hline
\end{tabular}

$\mathrm{Pb}$ compared to background levels. The result of laboratory analysis of $\mathrm{Pb}$ in soil was summarized (Table 3).

Geostatistical analysis was applied to the $\mathrm{Pb}$ lateral distribution. Geostatistics provide an advanced methodology which facilitates quantification of the spatial features of soil parameters and enables spatial interpolation. Generally, contour pattern of $\mathrm{Pb}$ value clearly shows that high value is concentrated in the middle and few north part of the study area (Figure 1). The middle part of study area has high traffic density, confirmed by traffic condition in Figure 2. Although we have deliberately avoided sampling close to major roads, it is easily noticed that the highest lead values correspond to the major traffic density, as shown in Figure 2.

During the 1990-2010 period, the number of vehicles (cars and motorbikes) and also the road increased significantly. The main road and traffic activity in study area were shown in Figure 2. Anthropogenic activity in study area results in elevated of lead concentration in top soil.

This must have led to some improvements in the environmental quality of the inner city but may have also led to a deterioration in soil quality in suburban areas. Moreover, the suburban environment was also subject to the effects of emission of vehicles and the development of rural enterprises. $\mathrm{Pb}$ in soil usually decreases with increasing distance from a road (Fakayode and Olu-Owolabi, 2003). Lin Jian et al. (2000) described the $\mathrm{Pb}$ concentrations in surface soil near the road were greater under heavy than light traffic. This is confirmed by the distribution map of $\mathrm{Pb}$ in the atmosphere in study area as shown in Figure 3. Vehicles emission was the primary pollution source.

The occurrence and frequency of higher concentrations of pollutants in the atmosphere primarily depend on the magnitude and distribution of the sources of emissions, local topography, climate conditions and type of pollutant. The level of the pollution is mainly in correla- 


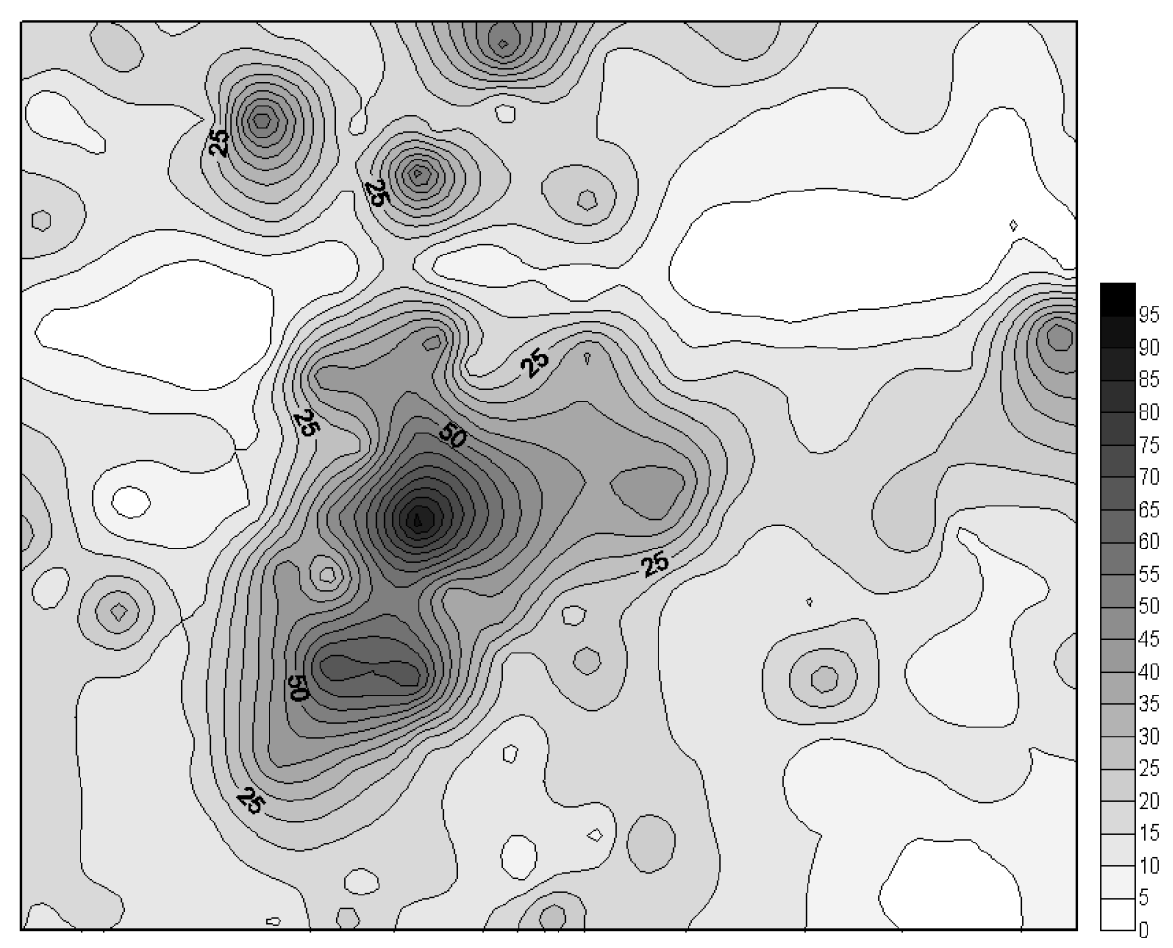

Figure 1: Distribution of $\mathrm{Pb}$ in soil in study area.

tion with the degree of the traffic density. However, because of topographical influence, wind speed, wind direction, vehicle speed and traffic flow, the peak of $\mathrm{Pb}$ contamination does not always occur near roads, and may have gaps from road location. This may be expressed by the slightly high concentration of $\mathrm{Pb}$ in soil the northern part of study area. As a result, $\mathrm{Pb}$ contamination occurs mainly in the surface soil due to human factors.

\subsection{Lead concentrations in different areas}

According to urban planning in Yogyakarta city, there are two area in the city: urban and suburban area. As expected, $\mathrm{Pb}$ concentrations in different urban areas differs, yet overall $\mathrm{Pb}$ contamination is higher in the urban area. The mean soil $\mathrm{Pb}$ concentration was $62 \mathrm{mg} / \mathrm{kg}$, about five times that in the suburban area (14 $\mathrm{mg} / \mathrm{kg}$ ) (Figure 4).

\subsection{Lead mobility on soil}

As mentioned earlier, the partitioning of soil was performed by the techniques proposed by Tessier et al. (1979). The chemical partition-
Table 4: Summarized statistical $\mathrm{Pb}$ soil data in urban and suburban area (mg/kg).

\begin{tabular}{l|c|c|c|c|c}
\hline & $\mathrm{N}$ & Min & Maks & Mean & Std. Dev \\
\hline Urban & 99 & 34 & 95.20 & 62 & 7.19 \\
\hline Suburban & 69 & 16 & 32 & 14 & 4.65 \\
\hline
\end{tabular}

ing of $\mathrm{Pb}$ in the selected soil at urban and suburban is shown in Figure 5. Despite the differences in $\mathrm{Pb}$ concentrations at the areas (urban and suburban), the distribution of $\mathrm{Pb}$ in five chemical fractions displayed a similar pattern. In general, the results showed that $\mathrm{Pb}$ was predominantly associated with the exchangeable fraction in the study areas, accounting for $\sim 50 \%$ of the total $\mathrm{Pb}$ in soil. The relatively high concentrations of lead in the exchangeable fractions of the soil may be attributed to $\mathrm{pH}$ level which encourages desorption of metals from soil. The presence of lead in the exchangeable fractions may pose a serious environmental concern since they are readily available for uptake by plants.

The second largest fraction of $\mathrm{Pb}$ was found in the carbonate fraction $(10-25 \%$ of the total $\mathrm{Pb}) . \mathrm{Pb}$ in the organic and residual fractions 


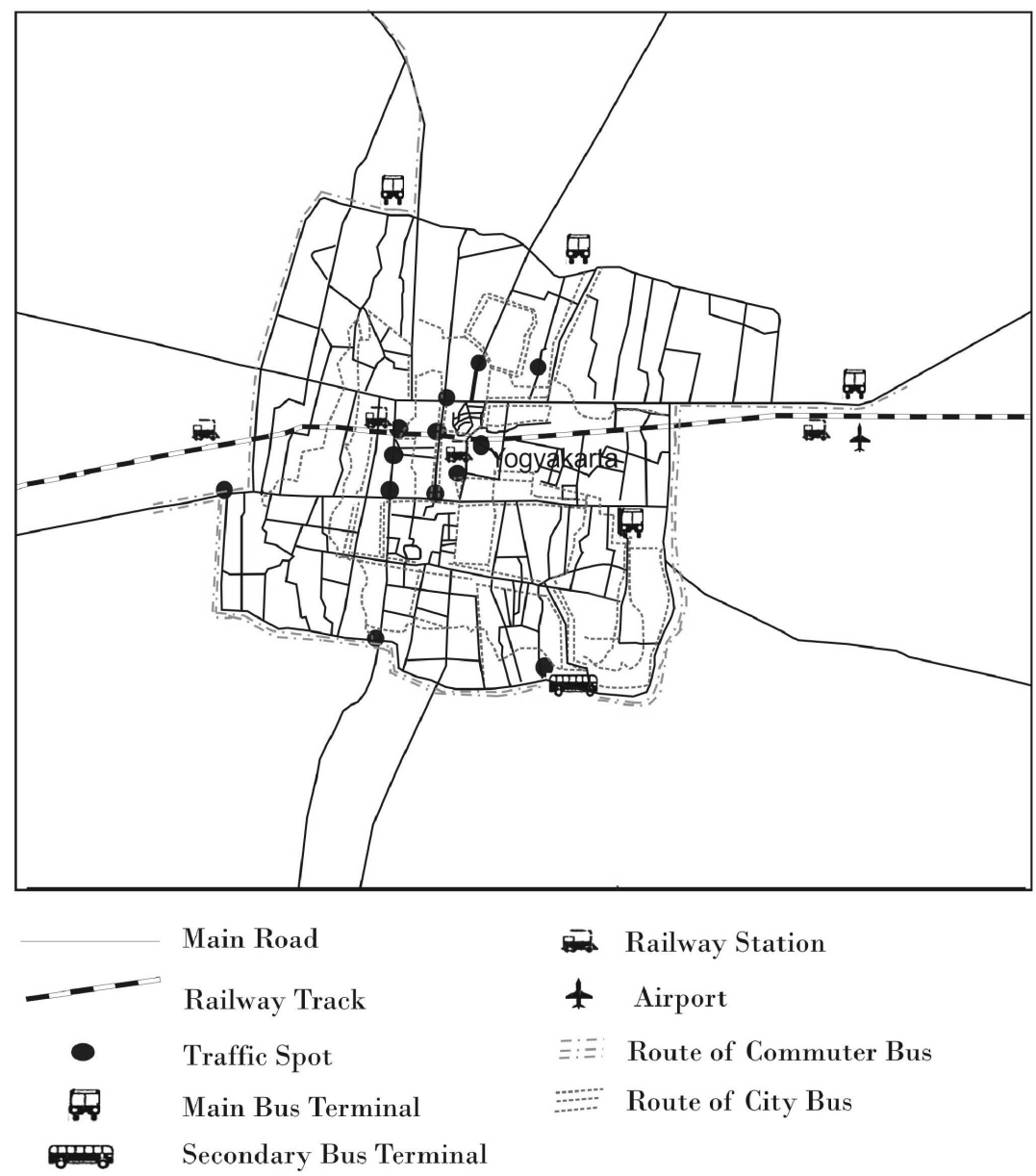

Figure 2: Traffic condition in study area (Yogyakarta Urban Air Quality Improvement ProgramUAQ-i, 2006. 


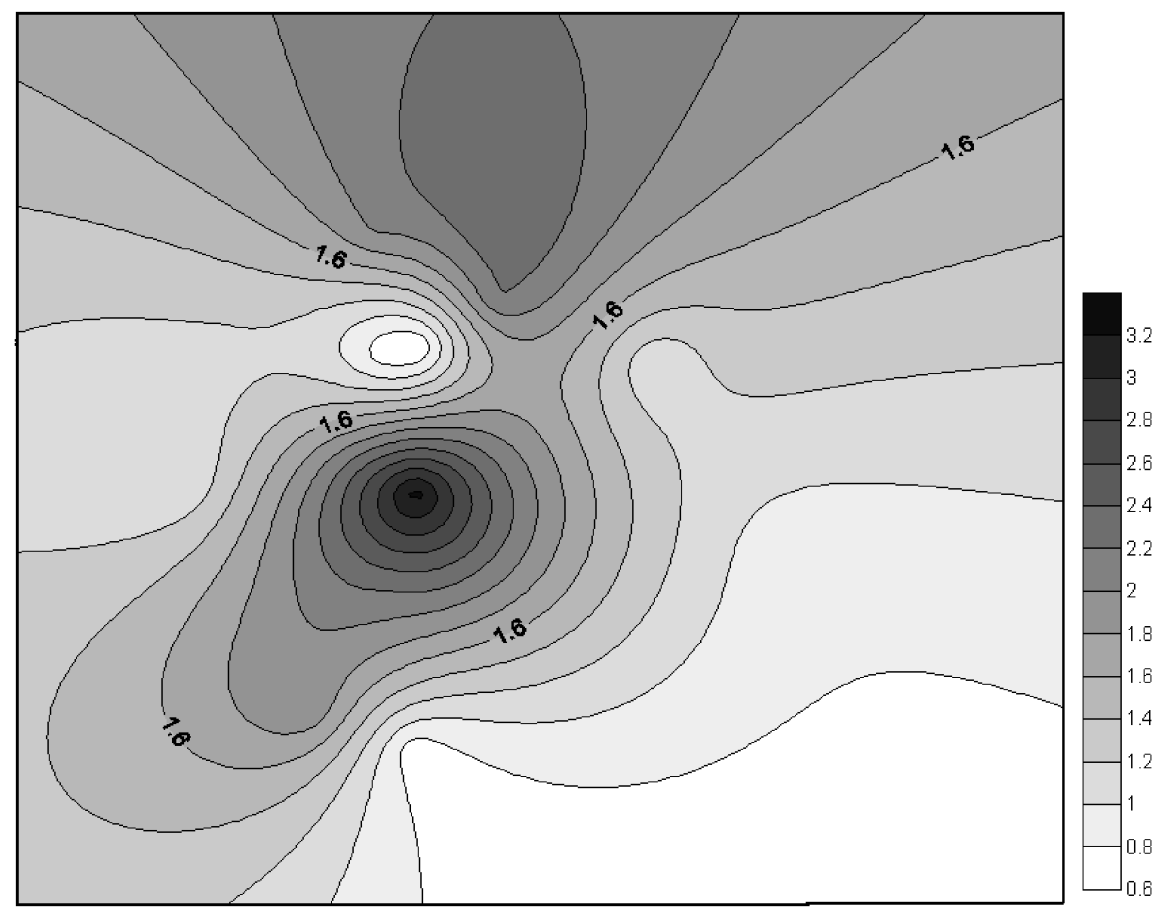

Figure 3: Distribution of $\mathrm{Pb}$ in atmosphere in study area (Yogyakarta Urban Air Quality Improvement Program-UAQ-i, 2006.

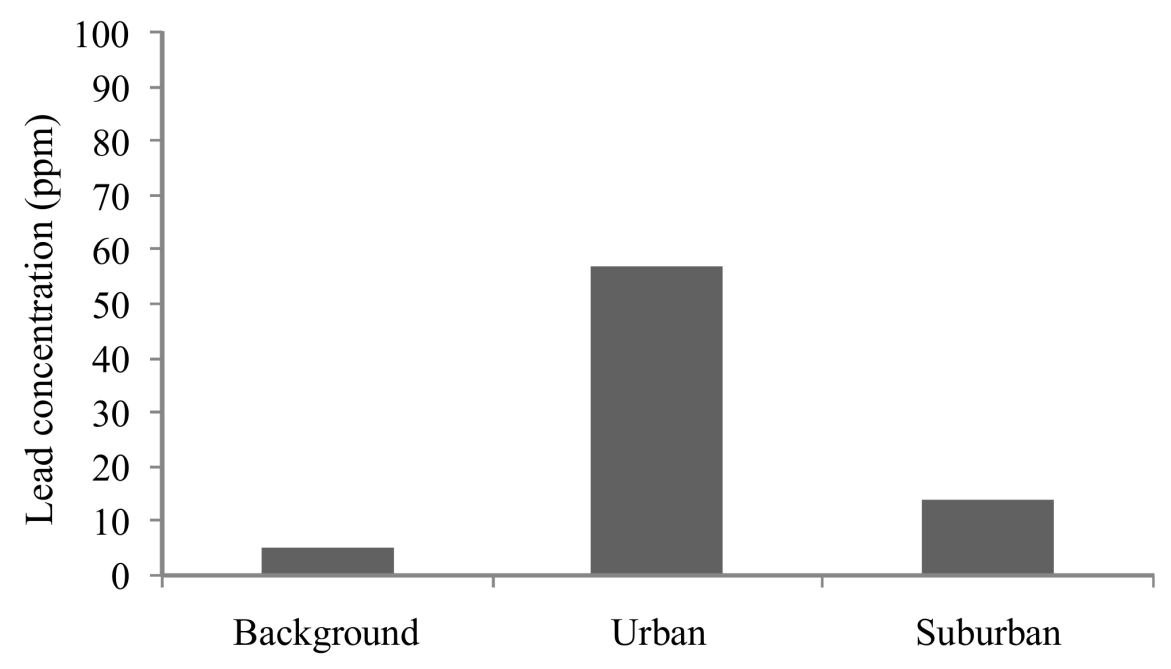

Figure 4: The mean of $\mathrm{Pb}$ concentration in the urban and suburban area. 


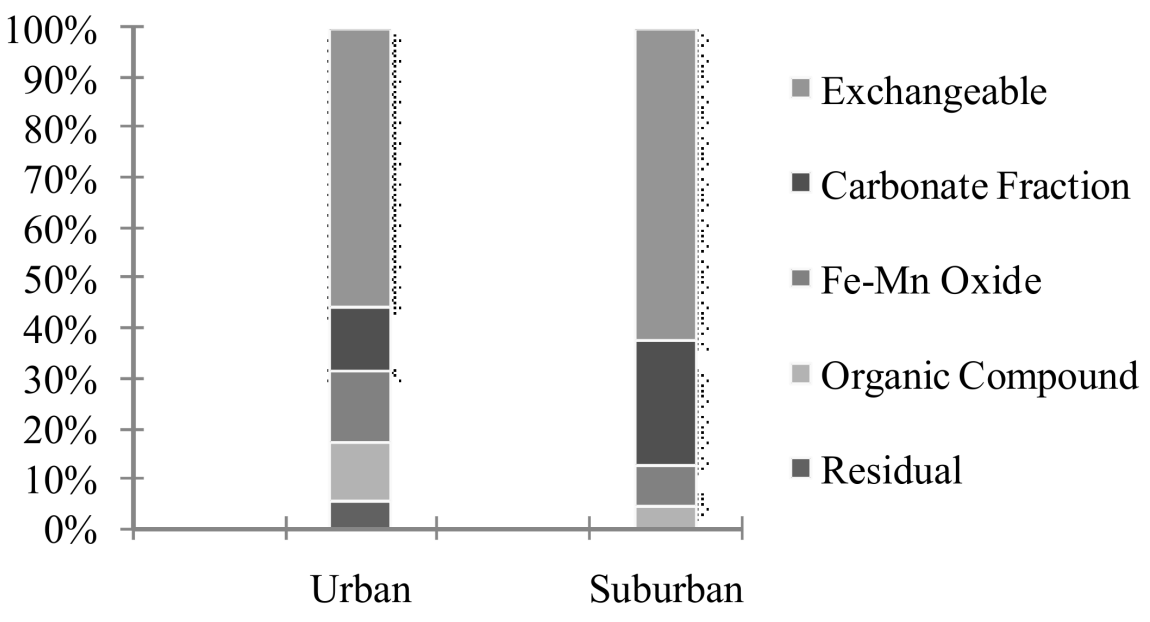

Figure 5: Chemical partitioning of $\mathrm{Pb}$ in study area.

collectively accounts for approximately 5-10\% of the total $\mathrm{Pb} . \mathrm{Pb}$ in the exchangeable fraction was the highest among the five fractions. Similar observation shows that the high mobility of lead, mainly in the upper soil horizon, may be caused by the enhanced amount of lead by atmospheric fallout (Plant and Raiswell, 1983). The very few proportion of metals found in the residual fraction shows the effect of parent material at soil formation. Metals in the residual fraction are only available after weathering or decomposition.

\section{Conclusion}

Results obtained in this study generally revealed the presence of $\mathrm{Pb}$ soil in Yogyakarta, with the most probable source of $\mathrm{Pb}$ is from motor vehicles via atmospheric deposition, although further study is needed to confirm these. The chemical partitioning of the $\mathrm{Pb}$ generally showed that the majority of the $\mathrm{Pb}$ in the soil was relatively unstable. The comparatively significant association of $\mathrm{Pb}$ with the exchangeable fractions indicated that $50 \%$ of the total $\mathrm{Pb}$ could be easily soluble and potentially bioavailable in these urban soil.

\section{References}

Alloway, B.J. (1990) Heavy Metals in Soil, Blackie, London.
Baiquni, M. (2004) Urbanization and Urban Settlement Dualism: A Case Study and Research of Yogyakarta, Indonesia, Proceeding of International Workshop on Asian Approach Toward Sustainable Urban Regeneration, September 2004, The University of Tokyo, Japan.

Budianta, W., (2009a) Assessment of Heavy Metals Distribution and Contamination in Surface Soil of Yogyakarta City, Proceeding 6th Annual Meeting of Asia Oceania Geoscience Society (AOGS), 1115 August 2009, Singapore.

Budianta, W, (2009b) A review of the heavy metal contaminaton of urban soil Yogyakarta City, Indonesia: Statistical Evidence, Proceedings 3rd International Contaminated Site Remediation Conference, 27-30 September 2009, Adelaide, Australia.

Budianta, W. (2010) Lead Contamination in Soil at Yogyakarta, Indonesia, Proceeding of 5th Annual International Symposium on Environment, 20-23 May 2010, Athens, Greece.

Facchinelli, A., Sachi, E., Mallen, L. (2000) Multivariate Statistical and GIS-based Approach to Identify Heavy Metal Sources in Soil, Journal of Environmental Pollution 114: 313-324.

Fakayode, S. O. and Olu-Owolabi, B. I. (2003) Heavy metal contamination of roadside topsoil in Osogbo, Nigeria: Its relationship to traffic density and proximity to highways. Journal Environmental Geology 44: 150-157.

Krauskopf, (1967) Introduction to Geochemistry, McGraw-Hill, New York, 721p.

Lin Jian, Qiu Qingru, Chen (2000) Assessment on pollution of heavy metals and metalloid in soil along road, Journal of Environment and Health 17: 284-286. 
Plant, J.A, and Raiswell, R. (1983) Principles of environmental geochemistry In: I. Thornton, Editors, Applied Environmental Geochemistry, Academic Press, London, pp. 1-39.

Rose, A. W., Hawkes, H. E., Webb, J. S. (1979) Geochemistry in Mineral Exploration, Academic Press, New York, 657p.

Subanu, L.P (2004) Urban dualism in Asian Cities: The Case Study Yogyakarta, Proceeding of International Workshop on Asian Approach Toward Sustainable Urban Regeneration, September 2004, The University of Tokyo, Japan.

Shi, W., Fisher, P. F., Goodchild, M. F. (2002) Spatial Data Quality, Taylor \& Francis, London.

Sir M MacDonald and Partners (1984) Greater Yogyakarta Groundwater Resources Study - Vol 2 Hydrology, Report of Groundwater Development Project (P2AT), Directorate General of water Resources Development, Ministry of Public Works, Government of the Republic of Indonesia, 174 pp.
Tessier, A., Campbell, P., Bisson, M. (1979) Sequential extraction procedure for the speciation of particulate trace metals, Analytical Chemistry 51: 844-851.

U.S. Environmental Protection Agency (2007) Science and Ecosystem Support Divisions for Soil Sampling, Athens, Georgia.

Wardhana and Muryono (2000) The Distribution of Heavy Metal on Street in Yogyakarta City Using APN Method (in Indonesian), Science Magazine of Energy, 8, Jakarta, Indonesia.

Webster, R. and Oliver, M. A. (2007) Geostatistics for Environmental Scientists, $2^{\text {nd }}$ Edition, John Wiley \& Sons, Ltd, England

Yogyakarta Urban Air Quality Improvement Program (UAQ-i) (2006) Final Draft of Technical Cooperation Project Between Indonesia - Asian Development Bank (ADB), Yogyakarta. 